\title{
Silver-Alumina Catalysts for Low-Temperature Methanol Incineration
}

\author{
Magdalena Jabłońska $^{1} \cdot$ Marek Nocuń $^{2} \cdot$ Ewa Bidzińska $^{1}$
}

Received: 3 February 2016/Accepted: 4 February 2016/Published online: 20 February 2016

(C) The Author(s) 2016. This article is published with open access at Springerlink.com

\begin{abstract}
The use of methanol as an alternative fuel for gasoline or diesel engines increases the unregulated $\mathrm{CH}_{3}$ $\mathrm{OH}$ emission. $\gamma-\mathrm{Al}_{2} \mathrm{O}_{3}$ modified with $\mathrm{Cu}, \mathrm{Mn}, \mathrm{Ce}, \mathrm{K}, \mathrm{Ag}$, $\mathrm{Cu}-\mathrm{Mn}, \mathrm{Cu}-\mathrm{Ce}, \mathrm{Cu}-\mathrm{Ag}$ or $\mathrm{Cu}-\mathrm{K}(0.5,1.0,0.5: 0.5,1.0: 1.0$ $\mathrm{wt} \%$ of metal) catalysed the process of methanol incineration. The highest activity reached samples containing 1.0 wt $\%$ of silver. Dispersed $\mathrm{Ag}^{+}$species on $\mathrm{Al}_{2} \mathrm{O}_{3}$ served as active species for selective oxidation of $\mathrm{CH}_{3} \mathrm{OH}$ to $\mathrm{CO}_{2}$ over both $\mathrm{Ag} / \mathrm{Al}_{2} \mathrm{O}_{3}$ and $\mathrm{Cu}-\mathrm{Ag} / \mathrm{Al}_{2} \mathrm{O}_{3}$. Additionally, the XPS and EPR results revealed the $\mathrm{AgO}$ interface between the $\mathrm{Ag}_{2} \mathrm{O}$ and $\mathrm{CuO}$ in the $\mathrm{Cu}-\mathrm{Ag}$ system.
\end{abstract}

\section{Graphical Abstract}

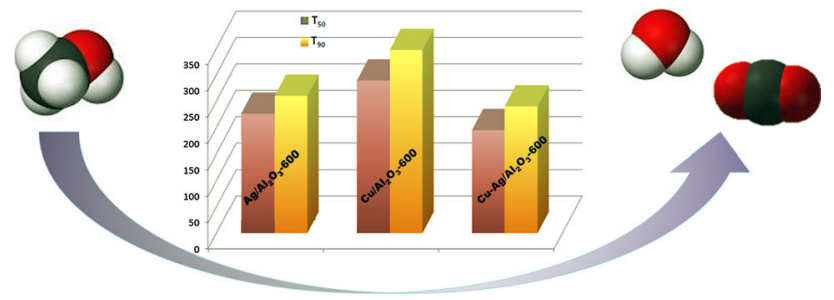

Keywords Alumina - Silver - Catalytic properties · Methanol incineration · VOCs

Magdalena Jabłońska

Magdalena.Jablonskaw@gmail.com

1 Faculty of Chemistry, Jagiellonian University, Ingardena 3, 30-060 Kraków, Poland

2 Faculty of Material Science and Ceramics, AGH University of Science and Technology, Mickiewicza 30, 30-059 Kraków, Poland

\section{Introduction}

Volatile organic compounds (VOCs) are organic compounds with the boiling points lower than $260{ }^{\circ} \mathrm{C}$ at a standard atmospheric pressure of $101.325 \mathrm{kPa}$. VOCs are recognized as major contributors to air pollution because of their toxicity in living organisms, especially in humans and their involvement in the formation of photochemical smog [1]. The catalytic combustion is currently considered as the most promising method in order to reduce emissions of volatile organic compounds into the atmosphere. The catalysts of VOCs combustion can be divided into two main groups: (i) noble metal catalysts and (ii) transition metal oxides (e.g. [2, 3]). The most commonly used carrier for the active phases is $\gamma-\mathrm{Al}_{2} \mathrm{O}_{3}$ (e.g. [4]). Detailed information about mentioned catalytic systems were given in comprehensive reviews (e.g. $[1,5,6]$ etc.). The catalysts containing platinum and palladium are the most widely implemented in practice due to their remarkable activity. E.g. among tested palladium supported on $\gamma-\mathrm{Al}_{2} \mathrm{O}_{3}(0.5-2.5 \mathrm{wt} \%$ of $\mathrm{Pd})$, the catalyst with palladium content of $1.0 \mathrm{wt} \%$ revealed maximum methanol oxidation at $225^{\circ} \mathrm{C}$ [3]. Silver-based catalysts have been less intensively studied for total combustion of VOCs. The studies of Cordi and Falconer [7] led to the conclusion that the $\mathrm{Ag} / \mathrm{Al}_{2} \mathrm{O}_{3}$ (2.1 wt\% of $\mathrm{Ag}$ ), was very active for the complete oxidation of various VOCs. Based on the largest $\mathrm{CO}_{2}$ peak (based on TPO analysis), it was suggested, that the relative oxidation activities followed the order:

formic acid $>$ methanol $>$ acetic acid $>$ ethanol $>$ acetaldehyde.

The silver supported on alumina was studied for oxidation of toluene (e.g. [8]) or acetone and pyridine 
oxidation [9]. E.g. optimum loading for the complete oxidation of toluene reached $11.0 \mathrm{wt} \%$ for $\mathrm{Ag} / \mathrm{Al}_{2} \mathrm{O}_{3}$. The addition of copper (1.0-5.0 wt\%) provided complete toluene oxidation at $250-260{ }^{\circ} \mathrm{C}$ [9]. Additionally, $\mathrm{HY}$ and HZSM-5 zeolites doped with silver (2.5-3.9 wt\%) were utilized for ethyl acetate with its total combustion around $350-400{ }^{\circ} \mathrm{C}$ (e.g. [10, 11]). $\mathrm{Ag} / \mathrm{HY}(1.0 \mathrm{wt} \%$ of $\mathrm{Ag})$ showed also activity for both toluene and methyl ethyl ketone with total oxidation below $350{ }^{\circ} \mathrm{C}$ [12]. Besides silver-based catalytic systems, a lot of studies report successful application of the $\mathrm{Cu}$-containing catalysts for VOCs elimination (including methanol) (e.g. [2, 13]).

Methanol is mainly used in automobiles-an additive or an alternative fuel for gasoline engines-due to its ability to produce power with lower emission of air pollutants (e.g. [14]). However, a large amount of methanol may be emitted as a result of its incomplete combustion [15]. The solution for its escape to the atmosphere could be catalytic oxidation of unburned methanol from exhaust gases. Depending on methanol blended fuels, applications temperature of exhaust gases may vary in the range of $300-450{ }^{\circ} \mathrm{C}$ for spark ignition engines [16] or below 200-300 ${ }^{\circ} \mathrm{C}$ for diesel engines (e.g. [14]).

In the present paper, we report results of the screening study of alumina-based catalysts in the range from 150 to $450{ }^{\circ} \mathrm{C}$. Moreover, we included detailed physicochemical characterization, such as: structural (XRD, EPR) and textural (BET) analysis; redox properties $\left(\mathrm{H}_{2}\right.$-TPR) and chemical surface composition (XPS). Our attention focused on the characterization of the active species of these catalytic systems.

\section{Experimental}

\subsection{Catalysts preparation}

$\gamma-\mathrm{Al}_{2} \mathrm{O}_{3}$ (Merck) was doped with $\mathrm{Cu}, \mathrm{Mn}, \mathrm{Ce}, \mathrm{K}, \mathrm{Ag}$, by the incipient wetness impregnation method using aqueous solutions of the following metal nitrates: $\mathrm{Cu}\left(\mathrm{NO}_{3}\right)_{2} \cdot 3 \mathrm{H}_{2} \mathrm{O}$ (Merck), $\mathrm{Mn}\left(\mathrm{NO}_{3}\right)_{2} \cdot 4 \mathrm{H}_{2} \mathrm{O}$ (Lach-Ner), $\mathrm{Ce}\left(\mathrm{NO}_{3}\right)_{3} \cdot 6 \mathrm{H}_{2} \mathrm{O}$ $(\mathrm{POCH}), \mathrm{KNO}_{3}$ (CHEMPUR), $\mathrm{AgNO}_{3}(\mathrm{POCH})$. The sequence of metal deposition in case of bimetallic systems were as follows: $\mathrm{Cu}-\mathrm{Mn}, \mathrm{Cu}-\mathrm{Ce}, \mathrm{Cu}-\mathrm{Ag}$ or $\mathrm{Cu}-\mathrm{K}$. Based on preliminary studies over alumina modified with palladium [3], samples were modified with two concentrations of metals, such as 0.5 or $1.0 \mathrm{wt} \%$. E.g. samples denoted as $(1.0 \mathrm{wt} \%) \mathrm{Cu}-\mathrm{Mn} / \mathrm{Al}_{2} \mathrm{O}_{3}$ contained $1.0 \mathrm{wt} \%$ of each of the deposited metal. All prepared samples were dried and subsequently calcined in static air at $600{ }^{\circ} \mathrm{C}$ for $12 \mathrm{~h}$. For catalytic experiments, a sieve fraction of particles with size of $0.160-0.315 \mathrm{~mm}$ was used.

\subsection{Catalytic tests}

All prepared materials were tested as catalysts in total methanol oxidation. The catalytic experiments were performed under atmospheric pressure in a fixed-bed flow microreactor system. The reactant concentration were continuously measured using a quadruple mass spectrometer RGA 200 (PREVAC) connected directly to the reactor outlet. Prior to the catalytic test, each sample of the catalyst $(100 \mathrm{mg})$ was outgassed in a flow of synthetic air at $500{ }^{\circ} \mathrm{C}$ for $30 \mathrm{~min}$. The isothermal saturator placed in an ice-water bath and with a constant flow of synthetic air was used for supplying of methanol into the reaction mixture. The composition of gas mixture at the reactor inlet was $\left[\mathrm{CH}_{3} \mathrm{OH}\right]=4.0 \mathrm{vol} \%, \quad\left[\mathrm{O}_{2}\right]=19.0 \quad \mathrm{vol} \%$ and $\left[\mathrm{N}_{2}\right]=77.0 \mathrm{vol} \%$. Total flow rate of the reaction mixture was $20 \mathrm{~cm}^{3} / \mathrm{min}$.

\subsection{Catalysts characterization}

The X-ray diffraction (XRD) patterns of the samples were recorded with a D2 Phaser diffractometer (Bruker) using $\mathrm{Cu} \mathrm{K} \alpha$ radiation $(\lambda=1.54060 \AA$, $30 \mathrm{kV}, 10 \mathrm{~mA})$.

The specific surface area $\left(\mathrm{S}_{\mathrm{BET}}\right)$ of the samples was determined by low-temperature $\left(-196{ }^{\circ} \mathrm{C}\right) \mathrm{N}_{2}$ sorption using Quantasorb Junior sorptometer (Ankersmit). Prior to nitrogen adsorption the samples were outgassed at $250{ }^{\circ} \mathrm{C}$ for $2 \mathrm{~h}$ in a flow of $\mathrm{N}_{2}$.

The temperature-programmed reduction $\left(\mathrm{H}_{2}-\mathrm{TPR}\right)$ patterns of samples $(30 \mathrm{mg})$ were performed using using a Quantachrome ChemBET Pulsar TPR/TPD instrument. $\mathrm{H}_{2}$-TPR runs were carried out starting from room temperature to $800{ }^{\circ} \mathrm{C}$, with a linear heating rate of $10^{\circ} \mathrm{C} / \mathrm{min}$ and in a flow $\left(6 \mathrm{~cm}^{3} / \mathrm{min}\right)$ of $5 \mathrm{vol} \% \mathrm{H}_{2}$ diluted in $\mathrm{Ar}$. Water vapour was removed from effluent gas by the means of a cold trap placed in an ice-water bath. The $\mathrm{H}_{2}$ consumption was detected and recorded by TCD.

X-ray photoelectron spectra (XPS) were measured on a VSW spectrometer equipped with a hemispherical analyser. The photoelectron spectra were measured using a magnesium $\operatorname{MgK} \alpha$ source $(\mathrm{E}=1253.6 \mathrm{eV})$. The base pressure in the analysis chamber during the measurements was $3 \times 10^{-6} \mathrm{~Pa}$ and the spectra were calibrated on a main carbon $\mathrm{C} 1 \mathrm{~s}$ peak at $284.6 \mathrm{eV}$. The composition and chemical surrounding of the sample surface were investigated based on the areas and binding energies of $\mathrm{Ag} 3 \mathrm{~d}, \mathrm{Cu}$ $2 \mathrm{p}, \mathrm{Al} 2 \mathrm{p}, \mathrm{C} 1 \mathrm{~s}$ and $\mathrm{O} 1 \mathrm{~s}$ photoelectron peaks. Mathematical analyses of the XPS spectra were carried out using the XPSpeak 4.1 computer software (RWM. Kwok, The Chinese University of Hong Kong).

The electron paramagnetic resonance (EPR) spectra were recorded at room temperature using an ELEXSYS E-500 spectrometer (Bruker) operating at the $100 \mathrm{kHz}$ field 
modulation. Prior to EPR measurements the samples were outgassed under high vacuum. In order to determine the integral intensity of the EPR spectra, double integrals of spectra were calculated.

\section{Results and discussion}

\subsection{Catalytic activity}

Alumina modified with different metals was tested in the process of methanol incineration. Figure 1 presents obtained results, while Table 1 summarizes $\mathrm{T}_{50}$ and $\mathrm{T}_{90}$ for the studied catalysts. $\mathrm{T}_{50}$ refers to the temperature needed to reach $50 \%$ methanol conversion, and it is widely use to compare catalytic activity in the same reaction conditions, while $\mathrm{T}_{90}$ is the temperature needed to obtain $90 \%$ methanol conversion. The obtained results showed full methanol conversion over all tested catalysts in the temperature range of $125-450{ }^{\circ} \mathrm{C}$. The exception was pure oxide support, for which $94 \%$ conversion of methanol was achieved at $450{ }^{\circ} \mathrm{C}$ (Fig. 1a). In the case of a catalyst containing $1.0 \mathrm{wt} \%$ of copper, complete conversion of the methanol was achieved at $400{ }^{\circ} \mathrm{C}$. The addition of the promoter, such as 0.5 and $1.0 \mathrm{wt} \%$ of potassium, resulted in both cases in a slight increase in catalytic activity with respect to $\mathrm{Cu} / \mathrm{Al}_{2} \mathrm{O}_{3}$ (Fig. 1b). Activating effect of potassium on copper catalysts is consistent with literature data (e.g. [13]).

The low activity of catalyst containing only manganese was obtained especially in the low temperature range. However, complete conversion of methanol over such catalytic system was reached at $375{ }^{\circ} \mathrm{C}$. In the scientific literature, manganese-containing materials are highly active catalysts of VOCs combustion, such as toluene, ethanol and butanol (e.g. [17, 18]). The addition of manganese $(0.5$ or $1.0 \mathrm{wt} \%)$ to a sample containing copper increased its catalytic activity, however only above $300{ }^{\circ} \mathrm{C}$ (Fig. 1b). The total conversion of methanol over (1.0 wt $\%) \mathrm{Mn}-(1.0 \mathrm{wt} \%) \mathrm{Cu} / \mathrm{Al}_{2} \mathrm{O}_{3}$ was achieved at $325{ }^{\circ} \mathrm{C}$-at temperature lower of about $75{ }^{\circ} \mathrm{C}$ compared to that obtained for $(1.0 \mathrm{wt} \%) \mathrm{Cu} / \mathrm{Al}_{2} \mathrm{O}_{3}$. Such results are in agreement with literature data, which showed that doping with manganese improved catalytic activity of the $\mathrm{Cu}-$ containing samples (e.g. [18]).

Increasing cerium content in the catalyst resulted in an increase in activity, but the value for methanol conversion was still lower than that of the sample containing the same amount of copper in the sample (Fig. 1a). The bimetallic $(\mathrm{Cu}-\mathrm{Ce})$ catalysts were more active compared to $\mathrm{Cu} / \mathrm{Al}_{2} \mathrm{O}_{3}$ only below $350{ }^{\circ} \mathrm{C}$ (Fig. 1b). On the other side, in the scientific literature the $\mathrm{Cu}-\mathrm{Ce}$ systems are widely discussed as potential commercial catalysts for VOC
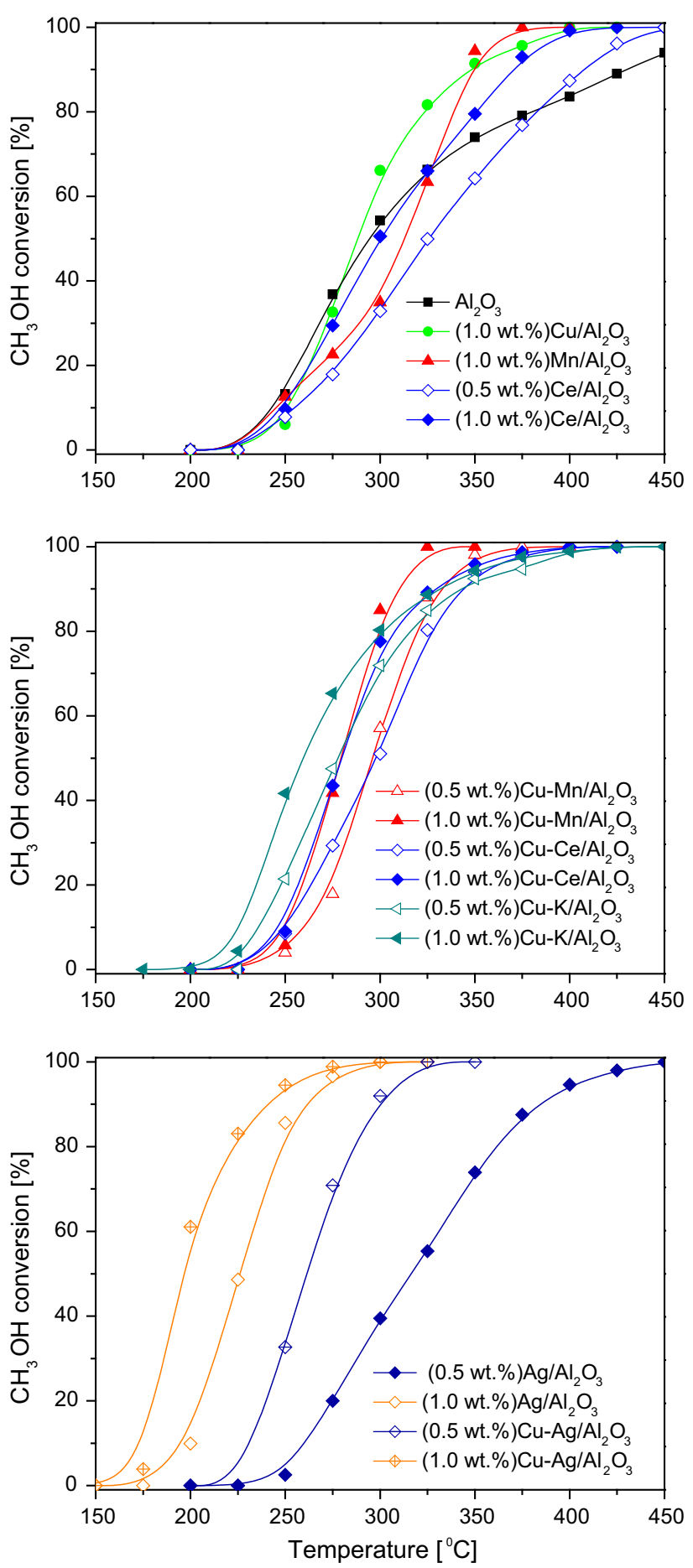

Fig. 1 Total incineration of methanol performed in the presence of commercial alumina and alumina-based catalytic materials. Reaction conditions: mass of catalyst $=100 \mathrm{mg},\left[\mathrm{CH}_{3} \mathrm{OH}\right]=4.0 \mathrm{vol} \%$, $\left[\mathrm{O}_{2}\right]=19.0 \mathrm{vol} \%$ and $\left[\mathrm{N}_{2}\right]=77.0 \mathrm{vol} \%$, total flow rate $=20 \mathrm{~cm}^{3} /$ min, linear heating of $10^{\circ} \mathrm{C} / \mathrm{min}$

combustion (e.g. [19]). Such discrepancies could be explained by different preparation methods, used supports as well as reaction conditions. An increase of catalytic activity with increasing metal content in the samples was 
Table $1 \mathrm{~T}_{50}$ and $\mathrm{T}_{90}$ temperatures of methanol incineration over catalysts and specific surface areas $\left(\mathrm{S}_{\mathrm{BET}}\right)$ of the catalytic materials

\begin{tabular}{|c|c|c|c|}
\hline Sample codes & $\mathrm{T}_{50}\left({ }^{\circ} \mathrm{C}\right)$ & $\mathrm{T}_{90}\left({ }^{\circ} \mathrm{C}\right)$ & $\mathrm{S}^{\mathrm{BET}}\left(\mathrm{m}^{2} / \mathrm{g}\right)$ \\
\hline $\mathrm{Al}_{2} \mathrm{O}_{3}$ & 295 & 431 & 135 \\
\hline$(1 \mathrm{wt} \%) \mathrm{Cu} / \mathrm{Al}_{2} \mathrm{O}_{3}$ & 289 & 347 & 98 \\
\hline$(1 \mathrm{wt} \%) \mathrm{Mn} / \mathrm{Al}_{2} \mathrm{O}_{3}$ & 314 & 347 & 99 \\
\hline$(0.5 \mathrm{wt} \%) \mathrm{Ce} / \mathrm{Al}_{2} \mathrm{O}_{3}$ & 326 & 407 & 92 \\
\hline$(1 \mathrm{wt} \%) \mathrm{Ce} / \mathrm{Al}_{2} \mathrm{O}_{3}$ & 299 & 368 & 91 \\
\hline$(0.5 \mathrm{wt} \%) \mathrm{Ag} / \mathrm{Al}_{2} \mathrm{O}_{3}$ & 317 & 386 & 91 \\
\hline$(1 \mathrm{wt} \%) \mathrm{Ag} / \mathrm{Al}_{2} \mathrm{O}_{3}$ & 226 & 260 & 89 \\
\hline$(0.5 \mathrm{wt} \%) \mathrm{Cu}-\mathrm{Mn} / \mathrm{Al}_{2} \mathrm{O}_{3}$ & 296 & 330 & 100 \\
\hline$(1 \mathrm{wt} \%) \mathrm{Cu}-\mathrm{Mn} / \mathrm{Al}_{2} \mathrm{O}_{3}$ & 280 & 308 & 82 \\
\hline$(0.5 \mathrm{wt} \%) \mathrm{Cu}-\mathrm{Ce} / \mathrm{Al}_{2} \mathrm{O}_{3}$ & 299 & 346 & 90 \\
\hline$(1 \mathrm{wt} \%) \mathrm{Cu}-\mathrm{Ce} / \mathrm{Al}_{2} \mathrm{O}_{3}$ & 280 & 330 & 86 \\
\hline$(0.5 \mathrm{wt} \%) \mathrm{Cu}-\mathrm{K} / \mathrm{Al}_{2} \mathrm{O}_{3}$ & 278 & 343 & 87 \\
\hline$(1 \mathrm{wt} \%) \mathrm{Cu}-\mathrm{K} / \mathrm{Al}_{2} \mathrm{O}_{3}$ & 259 & 333 & 85 \\
\hline$(0.5 \mathrm{wt} \%) \mathrm{Cu}-\mathrm{Ag} / \mathrm{Al}_{2} \mathrm{O}_{3}$ & 261 & 297 & 93 \\
\hline$(1 \mathrm{wt} \%) \mathrm{Cu}-\mathrm{Ag} / \mathrm{Al}_{2} \mathrm{O}_{3}$ & 195 & 240 & 88 \\
\hline
\end{tabular}

also observed for silver-based catalysts (Fig. 1c). The increase in the silver loading from 0.5 to $1.0 \mathrm{wt} \%$ greatly improved catalytic activity in the methanol incineration, and consequently its complete conversion over (1.0 wt $\%) \mathrm{Ag} / \mathrm{Al}_{2} \mathrm{O}_{3}$ occurred at $300{ }^{\circ} \mathrm{C}$. Furthermore, the bimetallic $\mathrm{Cu}-\mathrm{Ag}$ systems showed a higher value for methanol conversion (especially below $275^{\circ} \mathrm{C}$ ) compared to Ag-doped samples. However, the full conversion of methanol for all samples containing $1.0 \mathrm{wt} \%$ of silver was reached at $300{ }^{\circ} \mathrm{C}$. Analyzing the summarized results for the studied catalysts (Table 1), it could be concluded that among all utilized materials, the most active catalysts was the one containing $1.0 \mathrm{wt} \%$ of silver-with $\mathrm{T}_{90}$ of 260 and 240 for $\mathrm{Ag} / \mathrm{Al}_{2} \mathrm{O}_{3}$ and $\mathrm{Cu}-\mathrm{Ag} / \mathrm{Al}_{2} \mathrm{O}_{3}$, respectively. $\mathrm{CO}_{2}$ and water vapour were the only detected reaction products over both catalysts using QMS analysis.

\subsection{Physicochemical properties of the catalysts}

Figure 2 presents the powder XRD diffraction pattern obtained for the commercial alumina. Characteristic XRD diffraction peaks corresponding to the reflections of $\gamma-\mathrm{Al}_{2} \mathrm{O}_{3}$ were located at $19.9^{\circ}, 32.6^{\circ}, 37.5^{\circ}, 39.6^{\circ}, 45.9^{\circ}$, $61.1^{\circ}$ and $67.0^{\circ}$ [20]. No changes in the structure of oxide support appeared after impregnation with metals (results not shown).

Table 1 shows the specific surface areas $\left(\mathrm{S}_{\mathrm{BET}}\right)$ of alumina and its modifications with metals. Deposition of metals on the oxide support surface resulted in a decrease of specific surface areas $\left(82-100 \mathrm{~m}^{2} / \mathrm{g}\right)$ due to surface covering by the low surface area clusters of active components.

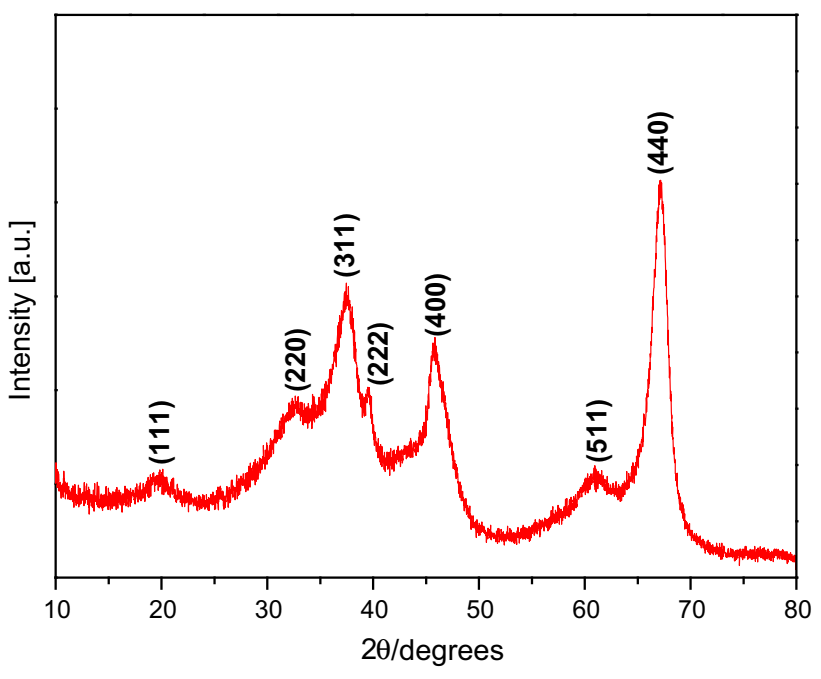

Fig. 2 XRD pattern of commercial $\gamma-\mathrm{Al}_{2} \mathrm{O}_{3}$

Figure 3 presents the $\mathrm{H}_{2}$-TPR profiles of copper and/or silver modified alumina. No reduction peaks appeared in the profiles recorded for pure $\gamma-\mathrm{Al}_{2} \mathrm{O}_{3}$. Two peaks centered around 110 and $385{ }^{\circ} \mathrm{C}$ appeared for $\mathrm{Ag} / \mathrm{Al}_{2} \mathrm{O}_{3}$; thus indicating two different silver oxide species. According to literature reports (e.g. [9, 21]), the first peak was ascribed to the highly dispersed $\mathrm{Ag}_{2} \mathrm{O}$, while the second one to the more aggregated $\mathrm{Ag}_{2} \mathrm{O}$. The reduction profile of pure $\mathrm{Ag}_{2} \mathrm{O}$ consisted on a single peak at $250{ }^{\circ} \mathrm{C}$, as it was reported earlier by Luo et al. [9]. They also investigated redox behaviour of $\mathrm{Ag} / \mathrm{Al}_{2} \mathrm{O}_{3}$ and claimed three kinds of $\mathrm{Ag}_{2} \mathrm{O}$ of different chemical environments in catalysts - the crystal $\mathrm{Ag}_{2} \mathrm{O}$ phase together with dispersed $\mathrm{Ag}_{2} \mathrm{O}$ phases (I,II), while the reduction of the former was reported to be easier than of the latter. However, in this studies, any silver oxide phases were identified in $\mathrm{Ag} / \mathrm{Al}_{2} \mathrm{O}_{3}$. Therefore, the second peak was ascribed to the reduction of $\mathrm{Ag}_{2} \mathrm{O}$ clusters on the $\gamma-\mathrm{Al}_{2} \mathrm{O}_{3}$, according to indications of Musi et al. [21].

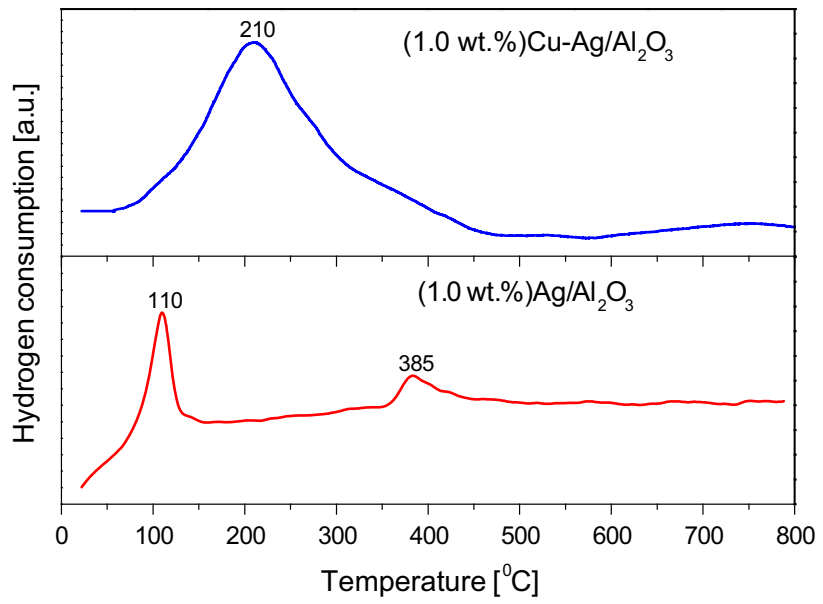

Fig. 3 TPR patterns of $\mathrm{Ag} / \mathrm{Al}_{2} \mathrm{O}_{3}$ and $\mathrm{Cu}-\mathrm{Ag} / \mathrm{Al}_{2} \mathrm{O}_{3}$ 


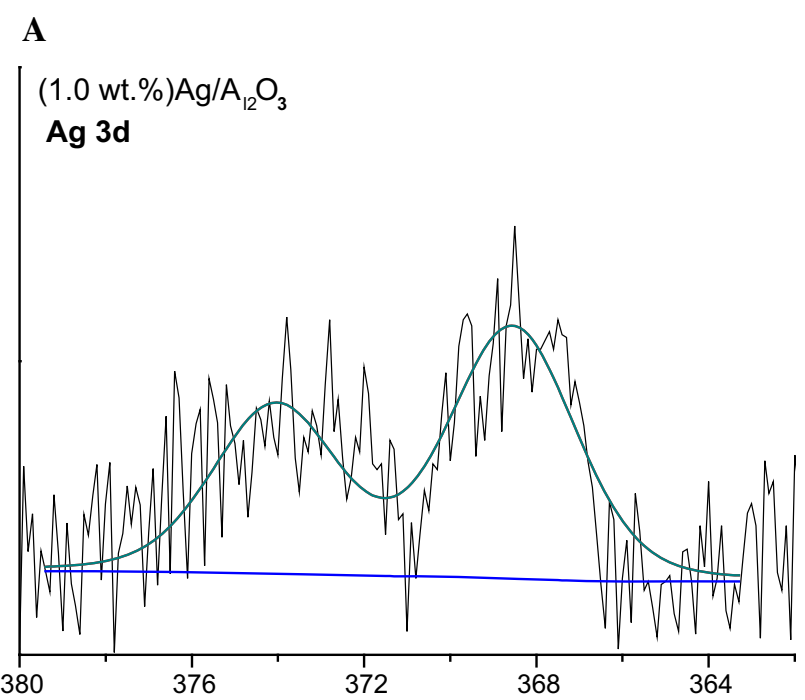

\section{B}
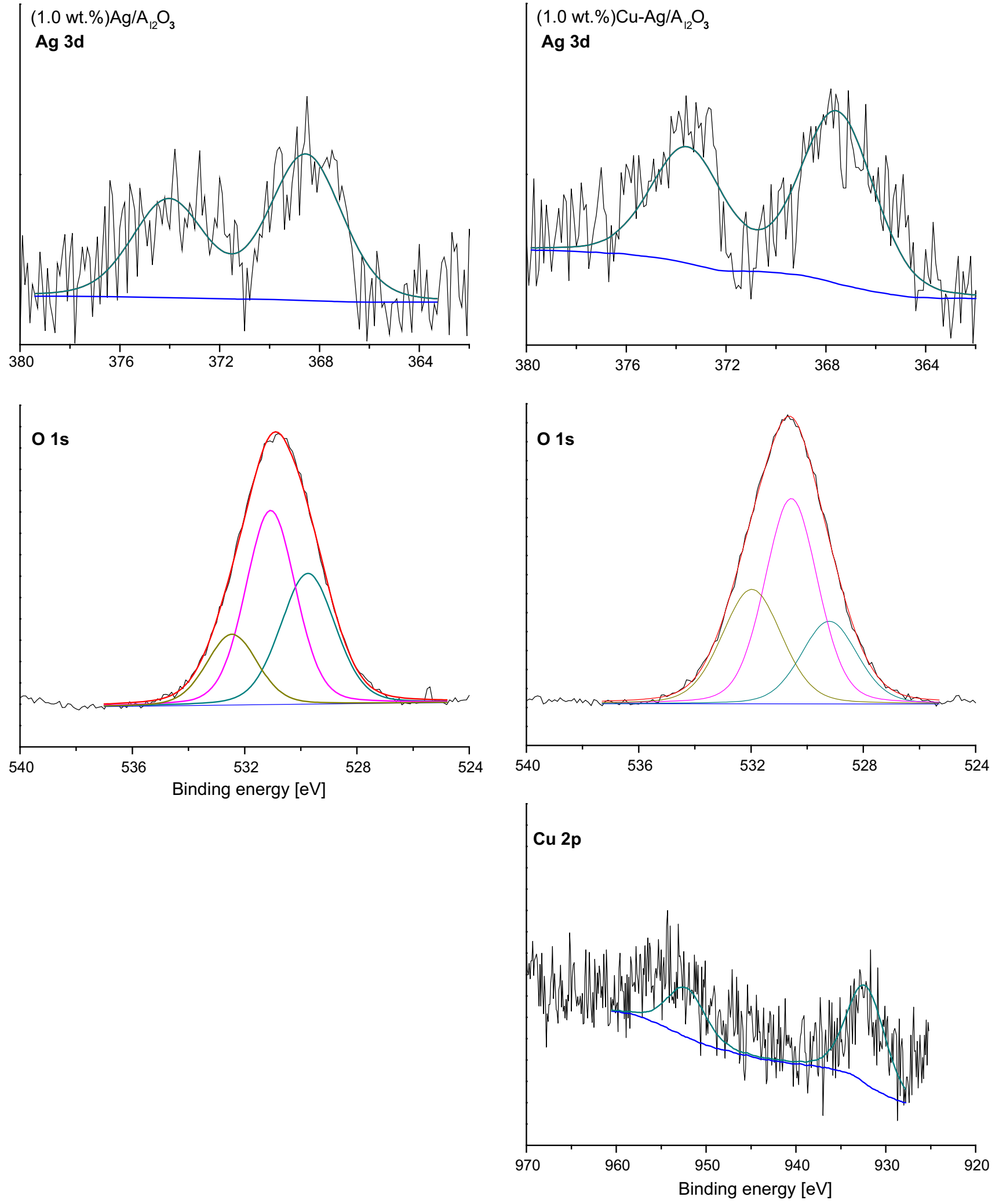

Fig. $4 \mathrm{XP}$ spectra in the range of binding energies for $\mathrm{Ag} / \mathrm{Al}_{2} \mathrm{O}_{3}$ (a) and $\mathrm{Cu}-\mathrm{Ag} / \mathrm{Al}_{2} \mathrm{O}_{3}$ (b) 
The TPR pattern of $(1.0 \mathrm{wt} \%) \mathrm{Cu} / \mathrm{Al}_{2} \mathrm{O}_{3}$ with main peak centred at about $304{ }^{\circ} \mathrm{C}$ was presented in our earlier studies [22]. Additionally, deposition of silver decreased the reduction temperature of the highly dispersed copper oxide species to $210{ }^{\circ} \mathrm{C}$. The bimetallic species can form either alloys or segregated core-shell structures (e.g. [23, 24]), which could be reduced at temperatures lower than pure copper oxide species. On the other side, $\mathrm{Cu}-\mathrm{Ag}$ alloys were reported to be thermodynamically unstable (e.g. [25]). The transmission electron microscopy (TEM) studies over $\mathrm{Cu}-$ $\mathrm{Ag} / \mathrm{Al}_{2} \mathrm{O}_{3}(2.5,7.5$ wt $\%$ of $\mathrm{Cu}, 2.5,7.5$ wt\% of $\mathrm{Ag})$ revealed intimate contact between copper and silver [25]. Consequently, the authors suggested that catalysts structure consists of a highly dispersed copper oxide (monolayer) on alumina upon which silver particles (of a very wide particle-size distribution) were situated. The proposed model seems to be valid also in case of our studies.

More information of the silver and copper state on the surface of alumina was obtained from XPS and EPR studies. Figure 4 and Table 2 summarize the X-ray photoelectron spectroscopy (XPS) results of $(1.0 \mathrm{wt} \%) \mathrm{Ag} /$ $\mathrm{Al}_{2} \mathrm{O}_{3}$ and $(1.0 \mathrm{wt} \%) \mathrm{Cu}-\mathrm{Ag} / \mathrm{Al}_{2} \mathrm{O}_{3}$. The most intense peak of $\mathrm{Ag} \mathrm{3d}$ occurred at about 368.8 and $368.1 \mathrm{eV}$ for the $\mathrm{Ag} / \mathrm{Al}_{2} \mathrm{O}_{3}$ and $\mathrm{Cu}-\mathrm{Ag} / \mathrm{Al}_{2} \mathrm{O}_{3}$, respectively. According to literature data, XPS peaks at 368.1-367.9 and 374.1-373.9 eV were ascribed to metallic $\mathrm{Ag} 3 \mathrm{~d}_{5 / 2}$ and $\mathrm{Ag}$ $3 \mathrm{~d}_{3 / 2}$. Additionally, the $\mathrm{Ag} 3 \mathrm{~d}_{5 / 2} \mathrm{BE}$ values in the range $367.7-367.6 \mathrm{eV}$ are characteristic of $\mathrm{Ag}_{2} \mathrm{O}$, while $\mathrm{AgO}$ range from 367.4 to $367.2 \mathrm{eV}$ [26]. However, many factors could influence the position of XPS peaks, including nature of the support and surrounding oxide species. Therefore, the XP peaks spectra of both samples were attributed to $\mathrm{Ag}_{2} \mathrm{O}$ species. Interestingly, according to the scientific indications the bonding energy of $\mathrm{Ag} 3 \mathrm{~d}_{5 / 2}$ for the bimetallic catalyst samples, i.e. $\mathrm{Cu}-\mathrm{Ag}$, have been reported to have positive peak shift compared to pure $\mathrm{Ag} / \mathrm{Al}_{2} \mathrm{O}_{3}$ (e.g. [24, 27]). On the other side, these results were

Table 2 XPS results of $\mathrm{Ag} / \mathrm{Al}_{2} \mathrm{O}_{3}$ and $\mathrm{Cu}-\mathrm{Ag} / \mathrm{Al}_{2} \mathrm{O}_{3}$

\begin{tabular}{llll}
\hline Sample code & Peak & $\begin{array}{l}\text { Position }^{\mathrm{a}} \\
(\mathrm{eV})\end{array}$ & FWHM $^{\mathrm{b}}$ \\
\hline (1.0 wt\%)Ag/Al $\mathrm{O}_{3}$ & $\mathrm{Ag} \mathrm{3d}$ & 368.8 & 3.4 \\
& $\mathrm{O} \mathrm{1s}$ & 529.8 & 2.3 \\
& & 531.1 & 2.1 \\
& & 532.5 & 2.1 \\
$(1.0 \mathrm{wt} \%) \mathrm{Cu}-\mathrm{Ag} / \mathrm{Al}_{2} \mathrm{O}_{3}$ & $\mathrm{Ag} \mathrm{3d}$ & 368.1 & 3.5 \\
& $\mathrm{O} \mathrm{1s}$ & 529.3 & 2.4 \\
& & 530.7 & 2.2 \\
& & 532.1 & 2.5 \\
& $\mathrm{Cu} \mathrm{2p}$ & 932.5 & 5.0 \\
\hline
\end{tabular}

${ }^{\mathrm{a}}$ Position of binding energy, ${ }^{\mathrm{b}}$ Full width at half-maximum obtained for materials after reduction with hydrogen. In our case, the binding energy for the $\mathrm{Cu}-\mathrm{Ag} / \mathrm{Al}_{2} \mathrm{O}_{3}$ sample had negative peak shift (368.8 eV $\rightarrow 368.1 \mathrm{eV})$. Moreover, $\mathrm{Ag}$ $3 \mathrm{~d}$ peak became slightly broader with a full width at halfmaximum (FWHM) from 3.4 to $3.5 \mathrm{eV}$. Thus, such effect was attributed to the possible generation of $\mathrm{Ag}^{2+}$ species as a result of strong interactions between silver and copper oxide species in $\mathrm{Cu}-\mathrm{Ag} / \mathrm{Al}_{2} \mathrm{O}_{3}$. These findings could be supported by XPS studies of Prieto et al. [23] over silvernickel nanoparticles (NPs) prepared by seed-mediated growth. The BE of Ag 3d for Ag-Ni NPs shifted towards lower values signifying the existence of oxidized silver.

Taking into account copper in the $\mathrm{Cu}-\mathrm{Ag} / \mathrm{Al}_{2} \mathrm{O}_{3}$ sample, the most intensive peak of $\mathrm{Cu} 2 \mathrm{p}$ occurred at about $932.5 \mathrm{eV}$ and was attributed to the $\mathrm{Cu}^{2+}$. These results were fully consistent with data presented by Gang et al. [25].

The results gained in both $\mathrm{H}_{2}$-TPR and XPS measurements fully correspond with the EPR analysis. Figure 5a shows, that the EPR spectrum of $\mathrm{Ag} / \mathrm{Al}_{2} \mathrm{O}_{3}$ sample revealed a very low intensity. Several authors reported that
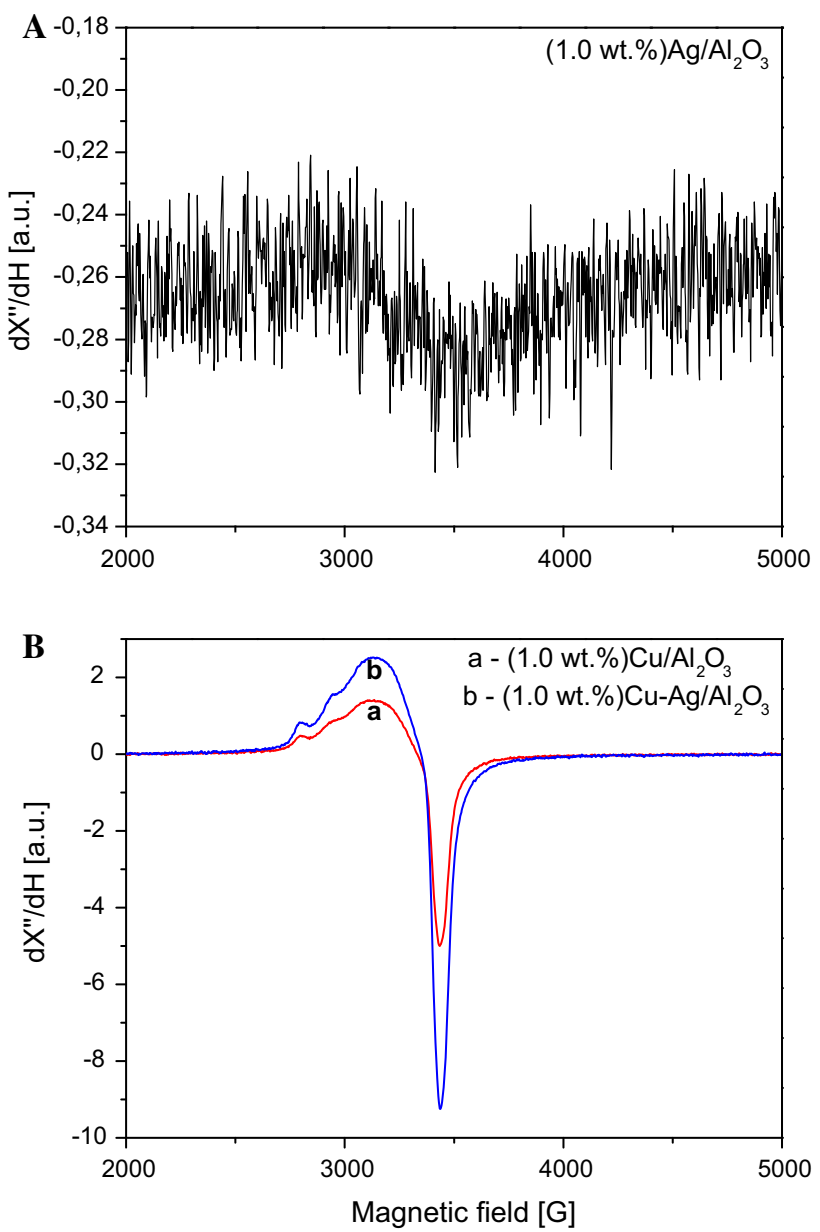

Fig. 5 EPR spectra of $\mathrm{Ag} / \mathrm{Al}_{2} \mathrm{O}_{3}(\mathbf{a}), \mathrm{Cu} / \mathrm{Al}_{2} \mathrm{O}_{3}$ and $\mathrm{Cu}-\mathrm{Ag} / \mathrm{Al}_{2} \mathrm{O}_{3}$ (b) 
$\mathrm{Ag}^{2+}$ ions can provide signal at $\mathrm{g}_{\text {iso }} \approx 2.20-2.30$ [28]. Thus, it can be concluded that only traces of $\mathrm{Ag}^{2+}$ were present in this sample. Since $\mathrm{Ag}^{+}$ions are diamagnetic, therefore, it could be stated that the silver was present in the sample mainly in the form of $\mathrm{Ag}_{2} \mathrm{O}$.

Spectra of $\mathrm{Cu} / \mathrm{Al}_{2} \mathrm{O}_{3}$ and $\mathrm{Cu}-\mathrm{Ag} / \mathrm{Al}_{2} \mathrm{O}_{3}$ (Fig. 5b) were typical for $\mathrm{Cu}^{2+}$ present in a magnetic environment having axial symmetry $\left(\mathrm{g}_{\perp}=2.04\right.$ and $\left.\mathrm{g}_{\|}=2.21\right)$ [29]. Thus, the obtained results indicated the presence of $\mathrm{CuO}$ in both samples. The weakly visible hyperfine structure originating in magnetic momenta of ${ }^{63} \mathrm{Cu}$ and ${ }^{65} \mathrm{Cu}$ nuclei $(\mathrm{I}=3 / 2)$ suggested the formation of small copper(II) oxide clusters. Comparing the intensities of spectra for samples containing the same copper loading $(1.0 \mathrm{wt} \%)$, it should be noted, that in the case of $\mathrm{Cu}-\mathrm{Ag} / \mathrm{Al}_{2} \mathrm{O}_{3}$, the integral intensity of the spectrum was about $60 \%$ higher than the intensity of $\mathrm{Cu} /$ $\mathrm{Al}_{2} \mathrm{O}_{3}$. Therefore, silver was possibly in the form of magnetically active $\mathrm{Ag}^{2+}$ or $\mathrm{Ag}^{0}$. The high calcination temperature of $600{ }^{\circ} \mathrm{C}(12 \mathrm{~h}$, static air), the same charges of $\mathrm{Ag}^{2+}$ compared to $\mathrm{Cu}^{2+}$ ions and their similar $\mathrm{g}_{\text {iso }}$, suggested that the increase in intensity originates from the presence of $\mathrm{Ag}^{2+}$. Following results were consistent with XPS interpretation in which comparing $\mathrm{Cu} / \mathrm{Al}_{2} \mathrm{O}_{3}$ and $\mathrm{Cu}-$ $\mathrm{Ag} / \mathrm{Al}_{2} \mathrm{O}_{3}$ samples, it was found that in the second sample there is more $\mathrm{Ag}^{2+}$. The results did not resolve the speciation of silver ions. Any evidence of metallic form of silver was found. Nevertheless, further detailed studies-and with different combinations of $\mathrm{Cu}-\mathrm{Ag}$ - proceeds to justify such findings.

\section{Conclusions}

Methanol as renewable and alternative energy source for the gasoline or diesel engine gain importance. Unregulated methanol emissions are one of the most serious concern regarding the use of low-content methanol applications. Therefore, suitable catalytic systems are highly required to meet future regulations.

In this study, we carried out a screening research of the activity of a series of catalysts- $\gamma-\mathrm{Al}_{2} \mathrm{O}_{3}$ modified $\mathrm{Cu}, \mathrm{Mn}$, $\mathrm{Ce}, \mathrm{K}, \mathrm{Ag}, \mathrm{Cu}-\mathrm{Mn}, \mathrm{Cu}-\mathrm{Ce}, \mathrm{Cu}-\mathrm{Ag}, \mathrm{Cu}-\mathrm{K}$-for the total methanol oxidation. The silver-based catalysts were very active for methanol incineration. An order of activity based on $\mathrm{T}_{90}$ over bimetallic catalytic systems with $1.0 \mathrm{wt} \%$ of metals were found as follows: $\mathrm{Ag}-\mathrm{Cu}>\mathrm{Mn}-\mathrm{Cu}>\mathrm{Ce}-$ $\mathrm{Cu}>\mathrm{K}-\mathrm{Cu}$. The $\mathrm{Ag}^{+}$species dispersed on alumina were responsible for high catalytic activity. Additionally, the XPS and EPR results confirmed the presence of $\mathrm{Ag}^{2+}$ at the interface between the $\mathrm{Ag}_{2} \mathrm{O}$ and $\mathrm{CuO}$.

Further studies are underway on activity and stability of $\mathrm{Cu}-\mathrm{Ag}$ system at lower methanol concentration as well as under real conditions of exhaust gases.
Acknowledgments Part of the research was done with equipment purchased in the frame of the European Regional Development Fund (Polish Innovation Economy Operational Program - Contract No. POIG.02.01.00-12-023/08).

Open Access This article is distributed under the terms of the Creative Commons Attribution 4.0 International License (http://crea tivecommons.org/licenses/by/4.0/), which permits unrestricted use, distribution, and reproduction in any medium, provided you give appropriate credit to the original author(s) and the source, provide a link to the Creative Commons license, and indicate if changes were made.

\section{References}

1. Li WB, Wang JX, Gong H (2009) Catal Today 148:81

2. Jabłońska M, Chmielarz L, Węgrzyn A, Góra-Marek K, Piwowarska Z, Witkowski S, Bidzińska E, Kuśtrowski P, Wach A, Majda D (2015) Appl Clay Sci 114:273

3. Jabłońska M, Król A, Kukulska-Zając E, Tarach K, Girman V, Chmielarz L, Góra-Marek K (2015) Appl Catal B 166167:353

4. Müller H, Deller K, Despeyroux B, Peldszus E, Kammerhofer P, Kuhn W, Spielmannleitner R, Stronger M (1993) Catal Today $17: 383$

5. Rusu AO, Dumitriu E (2003) Environ Eng Manag J 4:273

6. Huang H, Xu Y, Feng Q, Leung DY (2015) Catal Sci Technol $5: 2649$

7. Cordi EM, Falconer JL (1997) Appl Catal A 151:179

8. Kim SCh, Ryu JY (2011) Environ Technol 32:561

9. Luo MF, Yuan XX, Zheng XM (1998) Appl Catal A 175:121

10. Jodaei A, Salari D, Niaei A, Khatamian M, Çaylak N (2011) Environ Technol 32:395

11. Wong ChT, Abdullah AZ, Bhatia S (2008) J Hazard Mater 157:480s

12. Baek SW, Kim JR, Ihm SK (2004) Catal Today 93-95:575

13. Chmielarz L, Piwowarska Z, Rutkowska M, Wojciechowska M, Dudek B, Witkowski S, Michalik M (2012) Catal Commun 17:118

14. Yusaf T, Hamawand I, Baker P, Najafi D (2013) Int J Automot Mech Eng 8:1385

15. Zhang F, Wang JH, Tian DL, Wang JX, Shuai SJ, SAE Technical Paper 2013-01-1345

16. Devi EN, Bhatti SK, Priyadarsini ChI, MuraliKrisha MVS (2013) Int J Eng Res Appl 1351

17. Zimowska M, Michalik-Zym A, Janik R, Machej T, Gurgul J, Socha RP, Podobiński J, Serwicka EM (2007) Catal Today 119:321

18. Aguilera DA, Perez A, Molina R, Moreno S (2011) Appl Catal B 104:144

19. Dziembaj R, Molenda M, Zaitz MM, Chmielarz L, Furczoń K (2013) Solid State Ion 251:18

20. Wan H, Li D, Dai Y, Hu Y, Liu B, Dong L (2010) J Mol Catal A 332:32

21. Musi A, Massiani P, Brouri D, Trichard JM, Da Costa P (2009) Catal Lett 128:25

22. Jabłońska M (2015) Chem Papers 69:1141

23. Prieto P, Nistor V, Nouneh K, Oyama M, Abd-Lefdil M, Díaz R (2012) Appl Surf Sci 258:8807

24. Czaplińska J, Sobczak I, Ziółek M (2014) J Phys Chem C 118:12796

25. Gang L, Anderson BG, Van Grondelle J, van Santen RA, van Gennip WJH, Niemantsverdriet JW, Kooyman PJ, Knoester A, Brongersma HH (2002) J Catal 206:60 
26. Huang Y, Ariga H, Zheng X, Duan X, Takakusagi S, Asakura K, Yuan Y (2013) J Catal 307:74

27. Wang HK, Yi ChY, Tian L, Wang WJ, Fang J, Zhao JH, Shen WG (2012) J Nanomater 2012:4
28. Wang YP, Yeh CT (1991) J Chem Soc, Faraday Trans 87:345

29. Aboukaïs A, Bennani A, Aissi CF, Wrobel G, Guelton M (1992) J Chem Soc, Faraday Trans 88:615 